\title{
Race and empire
}

Eugenics in colonial Kenya

\section{CHLOE CAMPBELL}

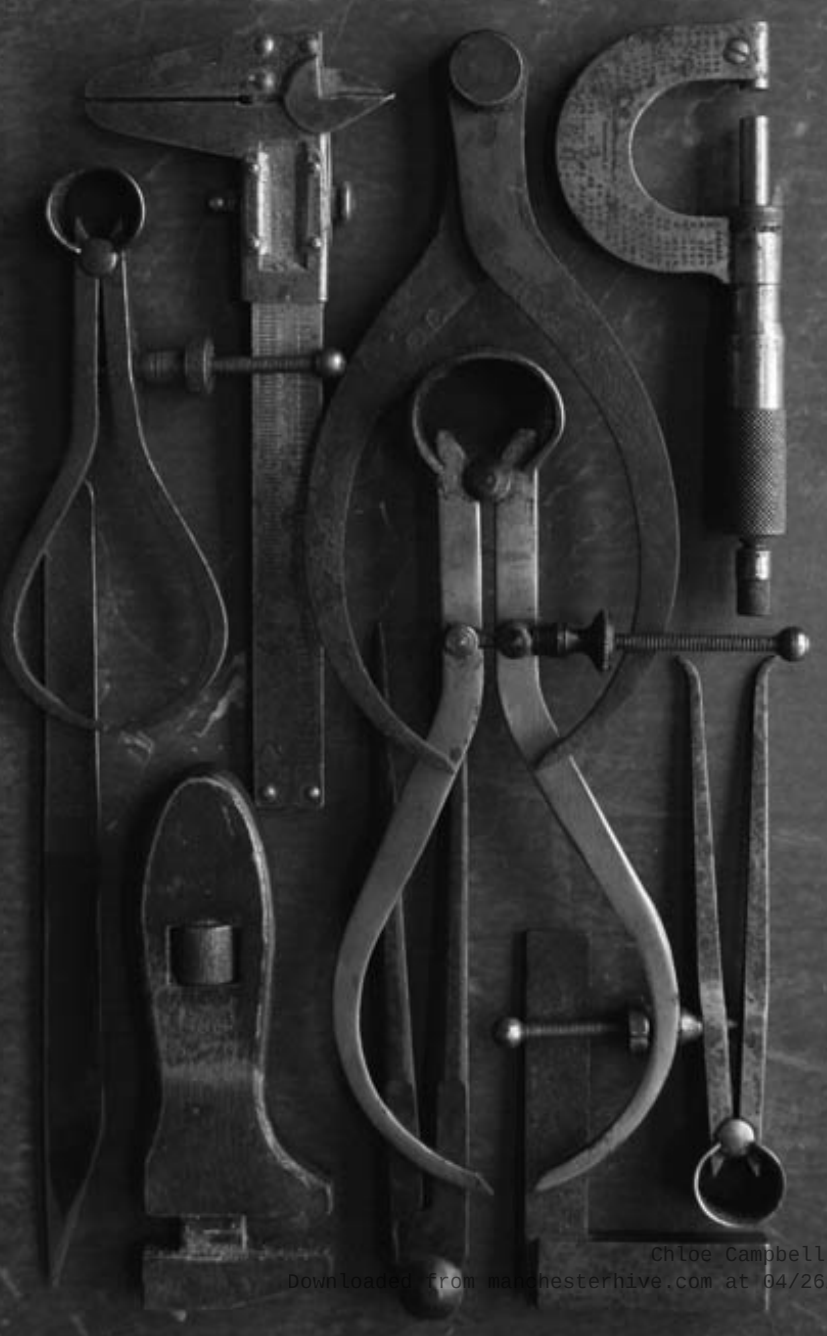




\section{IMPERIALISM}

general editor John M. MacKenzie

When the 'Studies in Imperialism' series was founded by Professor John M. MacKenzie more than thirty years ago, emphasis was laid upon the conviction that 'imperialism as a cultural phenomenon had as significant an effect on the dominant as on the subordinate societies'. With well over a hundred titles now published, this remains the prime concern of the series. Cross-disciplinary work has indeed appeared covering the full spectrum of cultural phenomena, as well as examining aspects of gender and sex, frontiers and law, science and the environment, language and literature, migration and patriotic societies, and much else. Moreover, the series has always wished to present comparative work on European and American imperialism, and particularly welcomes the submission of books in these areas. The fascination with imperialism, in all its aspects, shows no sign of abating, and this series will continue to lead the way in encouraging the widest

possible range of studies in the field. Studies in Imperialism is fully organic in its development, always seeking to be at the cutting edge, responding to the latest interests of scholars and the needs of this everexpanding area of scholarship.

Race and empire

\section{MANCHESTER 1824}

Manchester University Press 


\section{AVAILABLE IN THE SERIES}

CULTURAL IDENTITIES AND THE AESTHETICS OF BRITISHNESS ed. Dana Arnold BRITAIN IN CHINA

Community, culture and colonialism, 1900-1949 Robert Bickers IMPERIAL CITIES: Landscape, display and identity eds Felix Driver and David Gilbert

EQUAL SUBJECTS, UNEQUAL RIGHTS

Indigenous peoples in British settler colonies, 1830s-1910

Julie Evans, Patricia Grimshaw, David Phillips and Shurlee Swain

SCOTLAND, THE CARIBBEAN AND THE ATLANTIC WORLD, 1750-1820

Douglas J. Hamilton

EMIGRANT HOMECOMINGS

The return movement of emigrants, 1600-2000 Marjory Harper

REPORTING THE RAJ

The British press and India, c. 1880-1922 Chandrika Kaul

SILK AND EMPIRE Brenda M. King

LAW, HISTORY, COLONIALISM

The reach of empire eds Diane Kirkby and Catherine Coleborne

COLONIAL CONNECTIONS, 1815-45

Patronage, the information revolution and colonial government Zoë Laidlaw

PROPAGANDA AND EMPIRE

The manipulation of British public opinion, 1880-1960 John M. MacKenzie

THE OTHER EMPIRE

Metropolis, India and progress in the colonial imagination John Marriott

FEMALE IMPERIALISM AND NATIONAL IDENTITY

Imperial Order Daughters of the Empire Katie Pickles

SEX, POLITICS AND EMPIRE

A postcolonial geography Richard Phillips

MARRIED TO THE EMPIRE

Gender, politics and imperialism in India, 1883-1947 Mary A. Procida

IMPERIAL PERSUADERS

Images of Africa and Asia in British advertising Anandi Ramamurthy

IMPERIALISM AND MUSIC Britain, 1876-1953 Jeffrey Richards

THE HAREM, SLAVERY AND BRITISH IMPERIAL CULTURE

Anglo-Muslim relations, 1870-1900 Diane Robinson-Dunn

COLONIAL FRONTIERS

Indigenous-European encounters in settler societies ed. Lynette Russell

WEST INDIAN INTELLECTUALS IN BRITAIN ed. Bill Schwarz

\section{MIGRANT RACES}

Empire, identity and K. S. Ranjitsinhii Satadru Sen

AT THE END OF THE LINE

Colonial policing and the imperial endgame 1945-80 Georgina Sinclair

THE VICTORIAN SOLDIER IN AFRICA Edward M. Spiers

MARTIAL RACES AND MASCULINITY IN THE BRITISH ARMY, 1857-1914 Heather Streets

THE FRENCH EMPIRE BETWEEN THE WARS

Imperialism, politics and society Martin Thomas

BRITISH CULTURE AND THE END OF EMPIRE ed. Stuart Ward 


\title{
Race and empire
}

Eugenics in Colonial Kenya

\author{
Chloe Campbell
}

MANCHESTER UNIVERSITY PRESS

Manchester 
All material from the archive of the Eugenics Society (C) The Galton Institute, London

The right of Chloe Campbell to be identified as the author of this work has been asserted by her in accordance with the Copyright, Designs and Patents Act 1988.

Published by MANCHESTER UNIVERSITY PRESS

\section{ALTRINCHAM STREET, MANCHESTER, M1 7JA, UK}

www.manchesteruniversitypress.co.uk

British Library Cataloguing-in-Publication Data

A catalogue record for this book is available from the British Library

Library of Congress Cataloging-in-Publication Data applied for

ISBN 9780719071607 hardback

EISBN 9781847791351

First published 2007

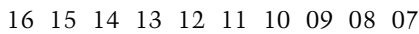

$\begin{array}{llllllllll}10 & 9 & 8 & 7 & 6 & 5 & 4 & 3 & 2 & 1\end{array}$

The publisher has no responsibility for the persistence or accuracy of URLs for any external or third-party internet websites referred to in this book, and does not guarantee that any content on such websites is, or will remain, accurate or appropriate.

Typeset

by Helen Skelton, Brighton, UK 